\title{
関東における夏季静穏日の水蒸気輸送に関する都市効果 URBAN EFFECT ON WATER VAPOR TRANSPORTATION OVER THE KANTO AREA DURING CALM SUMMER DAY
}

\author{
山中 徹*, 大岡 龍 三** \\ Toru YAMANAKA and Ryozo OOKA
}

\begin{abstract}
Moisture transportation by local circulation is examined during calm summer days at Kanto plain using meso-scale numerical model, in order to clarify an urban effect on the distribution of water vapor in the urban boundary layer. The numerical results show that the vertical velocity at sea breeze head is enhanced when sea breeze and thermal convection are combined in urban area near Tokyo. Because the combined updraft strongly lifts surrounding surface humid air, precipitable water vapor is increased around the urban area. CAPE indicates a little bit of decrease in atmospheric stability in the urban area on calm summer days.
\end{abstract}

Keywords : Moisture transportation, Urban effect, Sea breeze, Meso-scale model 水蒸気輸送, 都市効果, 海風，メソスケールモデル

\section{1. はじめに}

近年，都市域で発生する短時間強雨に対して社会的関心が高まっ ている。都市域を流域にもつ河川では, 流域の緑地が減少し人工地 表面が増加したことによって, 地表面からの浸透性が失われており， 流域に備わっていた保水・遊水機能が低下している。そのため, 短 時間に強い降雨が発生すると, 容易に地表面汇濫が生じ浸水被害を 拡げることになる 1)。その対策として, 都市部の河川流域では「特 定都市河川浸水被害対策法」が平成 15 年に制定され, 大規模開発 (雨水浸透阻害行為) において浸水対策を実施することが義務付け られるようになった。また, 短時間強雨は強い風を伴うことがあり, しばしば突風災害をもたらす。そのような激しい気象擾乱による被 害を軽減することを目的として, 首都圏を対象とした稠密観測プロ ジェクト 2)が進行している。それにより, 激しい気象擾乱の早期発 見・予測に向けた体制が整いつつあり, 公共交通事業 3)や建設業 4) における防災に, 予報を活用する社会実験も始まっている。ただし, 都市域で発生する短時間強雨への対策は，いまだに十分ではない。 例えば，東京都下水道局では，1 時間雨量 $50 \mathrm{~mm}$ を想定した浸水対 策を実施しているが，近年東京都で発生した内水汇濫では想定雨量 を上回る短時間強雨を観測している5)。都市域で発生する強い降雨 は, 都市機能に損傷を与えるばかりでなく, 都市居住者の安全も务 かす。都市域における降雨の発生プロセスを理解することは，有効
な対策を検討する上で重要であり，防災上大きな課題である。 都市域で発生する降雨には, 都市の存在が影響している可能性が 国内外で古くから指摘されている。特に，米国では盛んに研究が行 われてきた ${ }^{6)}$ 。例えば，1970 年代には，米国 6 都市において，都市 周辺から風下 $55 \mathrm{~km}$ の間で，夏季の降水量が $9 \%$ 17\%増加してい ることが示された 7)。近年では, 内陸のアトランタ 8) 9)で暖候期を対 象とした調査が成され，ヒートアイランド循環と降雨の関係 8)だけ でなく, 大気下層での水蒸気量の重要性が指摘された 9)。メキシコ 湾岸域のヒューストン 10$)$ では海風の関与が考察されている。

日本でも降雨に対する都市効果を調べた研究は多い。関東平野 (特 に東京）における夏季を対象とした先行研究のうち，気候学的な手 法を用いたものを以下に挙げる。Fujibe ら 11は，118 年間にわたる 東京での降雨観測記録を用いた分析から，暖候期の午後から夕方に 掛けて短時間降雨が増加傾向にあることを示した。さらに 30 年間 分の AMeDAS 観測記録を統計的に処理し，空間的にも東京都心部 に降雨量の正偏差があることを示している。佐藤ら ${ }^{12}$ は， 12 年間 の気象レーダを用いたコンポジット解析から, 夏季に山岳で発生し た強い降水エコーが都市域を通過する際に降水頻度が高まることを 示し，都市域では降水セルが発生し易い，もしくは再発達し易いこ とを示唆した。高橋ら ${ }^{13}$ は, 高密度な地上雨量データを分析し, 高 層ビル街の風下において降水頻度の極大域があることを示しており,
* 鹿島建設技術研究所先端・メカトロニクスグループ 上席研究員·工修

** 東京大学生産技術研究所 教授 $\cdot$ 博士 (工学)
Chief Research Engineer, Advanced Technology Incubation and Mechatronics Group, Kajima Technical Research Institute, M. Eng. Prof., I.I.S., the Univ. of Tokyo, Dr. Eng. 
高層ビルによる空気力学的な粗度効果に要因を求めている。また, 数值計算に基づいた例では, Kusaka ${ }^{14)}$ は, 領域気象モデル WRF を 用いて, 関東平野の夏季 (8月) について 7 年間分を計算し, 都市 をモデル化したケースでは, モデル化しないケースに比べて都市域 の降水量が多いことを示した。

夏季の関東平野において強雨発生プロセスは多様性があり ${ }^{15)}$ ，仮 に都市の存在が降雨の発生に関与するのであれば, その仕方も様々 であることが予想される。そのような場合, 一般論として都市効果 を導きだすためには, 様々な事例の分析を積み上げることが重要と なる。そこで, 個々の強雨事例を対象として, 都市効果を検出する 試みも多い。特に数值計算による事例解析では, 仮想的な数值実験 との比較を通じて, 降雨に対寸る都市効果を直接的に評価している。 例えば, 都市効果として, 高層建物が障壁となって風を遮る効果 ${ }^{16)}$ 17), 地表面からの加熱 18) 19)などが調心゙られており, その結果, 都市 効果によって都市域での下層収束（上昇気流）が強化されることを 示している。

水蒸気分布と局地的な短時間強雨との関係に着目した研究も進展 している。神田ら ${ }^{20}$ は, 局地的な短時間強雨の発生に先立って GPS 可降水量が増加する傾向にあることを示し, 可降水量が短時間強雨 の先行指標として利用できる可能性を示唆した。同様な傾向は, 日 下ら 21)も確認している。妹尾ら 22)は, 人工排熱（顕熱, 潜熱）が都 市域の可降水量の分布に与える影響を数值計算によって調べ, 人工 顕熱が増加すると都市域の可降水量が増えるとした。一方で, 日下 ら ${ }^{211}$ は, 降水前に都市域でヒートアイランドは明瞭に存在したもの の, ヒートアイランド循環によって水蒸気が集積し都市域で GPS 可降水量が増加する傾向は確認できなかったとしている。 Matheson ら ${ }^{23)}$ は, 関東平野で発生した短時間強雨 8 事例について, 数值計算によって都市の有無に対する感度分析を実施したところ, 都市域で降雨が増えた事例もあるが, 都市域下層に生じた乾燥空気 塊が移流することで場所によっては降雨が減る場合があると述べて いる。このように, 局地的な短時間強雨に先立った水蒸気の動態は 複雑であり, 十分に解明されていない。特に都市効果との関係には 不明な点が多い。また, 近年では, ヒートアイランド対策として, 緑化や保水性建材等を使用寸ることを推奨されている ${ }^{24)}$ 。これらの 対策は, 都市域から放出される顕熱を潜熱に変換し, 大気を加湿す ることになり，降雨との関連が懸念される。

本研究では, 降雨に対する都市効果の解明を最終目的とし, 数值 計算を用いた検討を行う。降雨に対する都市効果は, 個々の降雨事 例のみならず対象地域によっても, 特徴が異なる可能性がある。本 研究では, 対象地域として関東平野を取り上げる。関東平野は, 世 界有数の大都市である東京を内包し, 日本の人口が集中している地 域であり, 都市災害に備えるべき社会的要求が非常に高い。そのよ うな地域を対象とすることで, 都市計画ならび建築計画に関する考 察の一助となることを意図する。また, 局所的な循環による水蒸気 輸送に着目して, 都市が上空の水蒸気分布に与える影響について検 討する。これらにより降雨に対する都市効果一の理解が深まること が期待できる。まず, メソスケールモデルにより, 関東平野におけ る水蒸気の空間分布を再現し, 局所循環による水蒸気輸送について 分析する。さらに, 可降水量を用いて, 水蒸気輸送に対する都市効 果を定量的に評価することを試みる。

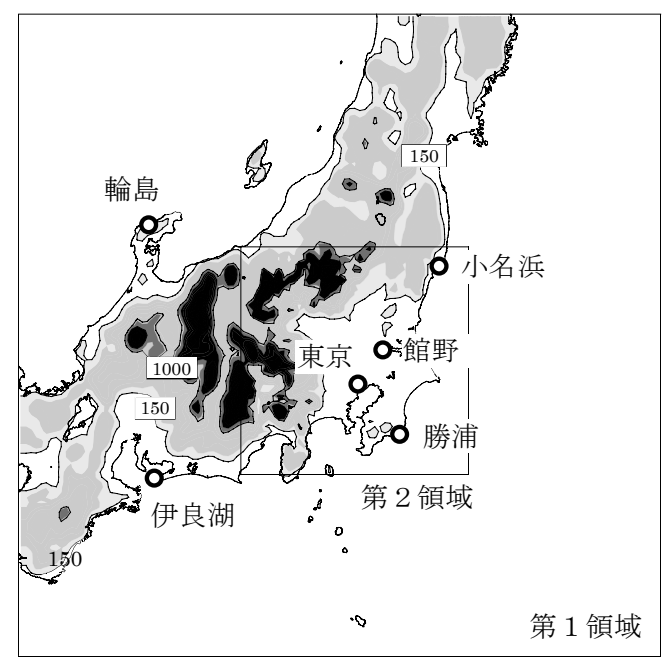

図 1 解析領域

\section{2. 検討対象日}

夏季の日中における都市ヒートアイランドや海風等の局地循環に 関する既往研究では, 晴天で風が弱い日を対象にすることが多い例え (゙ 25) 27)。また, 夏季の降水と地上風系の関係 ${ }^{28)}$ や局地循環による水 蒸気の動態 ${ }^{29)}$ を調べた既往研究でも, 地上気温が高温であること ${ }^{28)}$ や風が静穏 ${ }^{29)}$ であることを検討対象日の条件としている。本研究で も局所的な循環が卓越する夏季静穏日を検討対象とする。夏季静穏 日を抽出するために, 藤部ら ${ }^{28)}$ および佐々木ら ${ }^{29)}$ を参考にして, 以 下の条件を設定した。a）関東平野のアメダス観測地点の内, 島嶼を

\section{表 1 検討対象日}

\begin{tabular}{lll}
2005 年 8 月 4 日 & 2005 年 8 月 7 日 & 2006 年 8 月 4 日 \\
2005 年 8 月 5 日 & 2005 年 8 月 8 日 & 2006 年 8 月 29 日 \\
2005 年 8 月 6 日 & 2006 年 8 月 3 日 & \\
\hline
\end{tabular}

表 2 土地利用に対応した地表面パラメータ

\begin{tabular}{lcccccc}
\hline 国土数值情報 & $\begin{array}{c}\text { アルベド } \\
{[\%]}\end{array}$ & $\begin{array}{c}\text { 蒸発効率 } \\
{[\%]}\end{array}$ & $\begin{array}{c}\text { 放射率 } \\
{[\%]}\end{array}$ & $\begin{array}{c}\text { 粗度長 } \\
{[\mathrm{cm}]}\end{array}$ & $\begin{array}{c}\text { 熱慣性 } \\
{\left[\frac{\mathrm{J}}{\mathrm{cm}^{2} \mathrm{~K} \mathrm{~s}^{1 / 2}}\right]}\end{array}$ \\
$\begin{array}{l}\text { 建物用地 } \\
\text { 幹線交通用地 }\end{array}$ & 15 & 10 & 88 & 80 & 0.13 \\
$\begin{array}{l}\text { その他の用地 } \\
\text { その他の農用地 }\end{array}$ & 17 & 30 & 98.5 & 15 & 0.17 \\
田 & 18 & 50 & 98.5 & 10 & 0.17 \\
ゴルフ場 & 19 & 15 & 96 & 12 & 0.13 \\
森林 & 13 & 30 & 97 & 50 & 0.17 \\
河川地及び湖沼 & 8 & 100 & 98 & 0.01 & 0.25 \\
海水域 & 8 & 2 & 90 & 1 & 0.08 \\
荒地 & 25 & 2 & 92 & 12 & 0.13 \\
海浜 & 19 & 15 & & &
\end{tabular}

表 3 解析諸元

\begin{tabular}{ll}
\hline 境界層スキーム & MRF \\
粗度長スキーム & Garratt \\
積雲パラメタリゼーション & 未使用 \\
雲物理スキーム & Goddard 微物理モデル \\
放射スキーム & 雲放射を考慮 \\
地表面スキーム & 5 層土壌モデル \\
\hline
\end{tabular}


除く標高が $150 \mathrm{~m}$ 未満の地点を対象とした。b）それらの地点におい て日最高気温の平均が $30^{\circ} \mathrm{C}$ 以上であり, c) 9 時〜 15 時までの平均 日照時間が 2 時間以上あり, d) 6 時〜 12 時における降水量が $1 \mathrm{~mm}$ 以上の地点が 5 地点以下の日を抽出した。さらに, e) 一般風（定義 は後述）が $3.0 \mathrm{~m} / \mathrm{s}$ 以下であることを静穏日の条件とした。一般風 とは, 地形等による影響を受けない広い地域を代表する風を指す。 一般風の算出過程は, 関東地方を取り巻く小名浜, 輪島, 伊良湖, 勝浦の 4 地点の海面更正気圧の日平均值を用いて, 等圧面を最小自 乗法によって決定し, その気圧傾度を用いた地衡風の関係から算出 した。また, 地上天気図を参照し, 関東平野の近くに台風や前線が 解析されている日は除いた。このような作業を 2005 年, 2006 年の 8 月に対して実施し, 表 1 に示寸 8 日間を抽出した。ただし, 2006 年 8 月 4 日は, 一般風が $3.05 \mathrm{~m} / \mathrm{s}$ であり上記の条件 d)を満たさなか ったが，対象日をなる心゙く多くする観点から加えた。これらの条件 は, 夏季静穏日における局地循環の平均的な特徴を抽出することを 意図している。そのため, 局地循環が卓越するように, 日中に日照 があり, 特に午前に降雨がほぼ無いことを条件とした。しかし, 午 後に発生する降雨の有無については条件を課していない。選定日の 中で午後に関東平野に降雨を観測したのは 4 日間である。

選定条件 a)，b)，d)は，藤部ら ${ }^{28)}$ が設定した基本条件を参考にして いるが，藤部ら ${ }^{28)}$ では日最高気温の平均值を $28^{\circ} \mathrm{C}$ 以上としている ところが本研究とは異なる。これは, 夏季の関東地方における都市 ヒートアイランドの典型的な状況 ${ }^{26)}$ では, 日中の高温域 $\left(34 \sim 35^{\circ} \mathrm{C}\right)$ が平野部の広い範囲に及ぶことを参考にして, 本研究では日最高気 温の閾值を上げたことによる。選定条件 c), e)は, 佐々木ら ${ }^{29)}$ が設 定した選定条件を参考にしている。ただし, 佐々木ら ${ }^{29)}$ の条件では 関東平野に日照があることが保証されないため, 本研究では平均日 照時間を算出する地点を関東平野内に限定した。また, 対象日を増 やすために平均日照時間の閾值を 4 時間 ${ }^{29)}$ から 2 時間に短くしてい る。

\section{3. 検討方法}

\section{1 解析モデル}

本研究では, 非静力学メソスケールモデル MM5 $5^{30)}$ (PSU/NCAR Mesoscale Model $5^{\text {th }}$ generation) を用いて検討を行ったが，川本 ら ${ }^{311}$ によって改良された MM5 を用いた。改良版 MM5 では地表面境界 条件として地表面パラメータ（アルベド, 粗度長など）を設定する にあたり, 国土数值情報の土地利用データに基づいている。また, 計算格子内における土地利用区分の面積比に応じて地表面パラメー 夕を加重平均して与えることができる。国土数值情報の土地利用デ ータに対して割り当てた地表面パラメータを一覧にして表 2 に示す。 また, 東京都のエネルギ消費関連資料 ${ }^{32)}$ に基づいた人工排熱を地上 第一格子に全て顕熱として付与した。詳細は川本ら ${ }^{31}$ を参照された い。

ここで，人工排熱の顕熱・潜熱割合について注記する。足永ら ${ }^{33)}$ は, 東京 23 区における人工排熱を調べ, 夏季日中の全排熱量のうち 潜熱量は 25\%〜28\%を占めるとした。また, 妹尾ら ${ }^{22)}$ は, 同 $15 \%$ と ており, 全排熱量の中に潜熱量が占める割合は少なくない。ただし, 妹尾ら ${ }^{22)}$ によると, 夏季の晴天日において, 人工顕熱が増加すると 局地循環が強化され局地的な水蒸気量の分布に影響を与えるが，人
工潜熱は水蒸気分布にほとんど影響しないとしている。本研究では, 人工排熱における潜熱割合をゼロとしている。これは，人工顕熱が 局地循環による水蒸気輸送に与える影響を確認寸るために, 簡単な モデル（潜熱割合ゼロ）を使用し，結果解釈の複雑さを避けること を意図している。また, 夏季に外気温度が上がると, 冷房需要が増 え空調用エネルギ消費量が大幅に増加することが知られており ${ }^{34)}$, それに伴い人工排熱量も大きくなることが予想される。本研究では, 夏季の高温日 $\left(30^{\circ} \mathrm{C}\right.$ 以上) を対象としているため, 人工排熱量を割 増す必要がある可能性があるが, 人工排熱量の気温依存性について 十分な知見の蓄積がないため, 人工排熱の割増はしない。

関東平野を含む $768 \mathrm{~km}$ 四方を解析領域とし，その内側に $272 \mathrm{~km}$ 四 方の領域を入れ子状に設けた。解析領域を図 1 に示す。外側領域と 内側領域はネスティング手法を用いて 2-way で接続している。水平 方向の格子間隔は, 外側領域が $6 \mathrm{~km}$, 内側領域が $2 \mathrm{~km}$ である。鉛直 方向の計算格子は不等間隔に 37 層設けた。解析領域の上端は $30 \mathrm{hPa}$ （約 $19 \mathrm{~km}$ ）であり，地表面に最も近い格子は高度約 $40 \mathrm{~m}$ である。

MM5 では各種の物理パラメタリゼーションが提供されているが, 計算に使用した物理パラメタリゼーションの諸元を表 3 に示す。

\section{2 初期值}

初期值, 境界值は NCEP 最終解析データ (fn1) を元にして, 三次 元変分法によって各種の気象観測記録を同化して作成した。まず, NCEP 最終解析データを初期值および境界值として, 対象日の前日 9 時 JST から計算を開始した。さらに，6 時間毎に MM5 による予測值 を第一推定值として用いて, 3 次元変分法によって観測データを同 化した。データ同化は 2 回実施し, 対象日の前日 21 時 JST 時点での データ同化結果を最終的な初期值とした。同化した観測データは, NCEP が提供している陸上および海上の観測データ (ds464.0), 高層 観測データ (ds353.4) であり, さらに日本の気象庁が提供している ウィンドプロファイラのデータも同化した。3 次元変分法によるデ 一タ同化には NCAR が提供している $\operatorname{wrfvar} 2.1^{35))}$ を用いた。データ 同化サイクルの詳細は既報 ${ }^{36)}$ を参照されたい。データ同化に必要と される背景誤差共分散は, 2005 年 8 月 1 ケ月間を対象とした 12 時 間予測值と 24 時間予測值から NMC 法 ${ }^{37)}$ を用いて作成した。このよ うに作成した背景誤差は 12 時間予報誤差に当たるが, 本検討の同化 サイクルは前述のように 6 時間であり, 時間スケールが半分になる。 よって, 背景誤差共分散のスケーリングパラメータを 0.5 に設定し た。また，同化する観測記録の空間的な影響範囲に関するスケーリ ングパラメータは, 経験的に 0.15 に設定した。

\section{3 計算ケース}

本研究では, 水蒸気輸送に係る都市の効果を調べるために, これ までに示した諸元による計算ケースの他に，土地利用区分（表 2 参 照）において, 都市に相当する「建物用地, 幹線交通用地, その他 の用地」を「田」に変更した計算ケースも実施した。前者を基本ケ 一ス，後者を都市なしケースと称す。以下では，断りが無ければ計 算結果は全て基本ケースの結果を示している。

\section{4. 関東地方における水蒸気量}

\section{1 地上における水蒸気分布}

対象日における地上での水蒸気分布を観測記録から確認する。さ らにメソスケールモデル MM5 による気象の再現性を観測記録と比較 


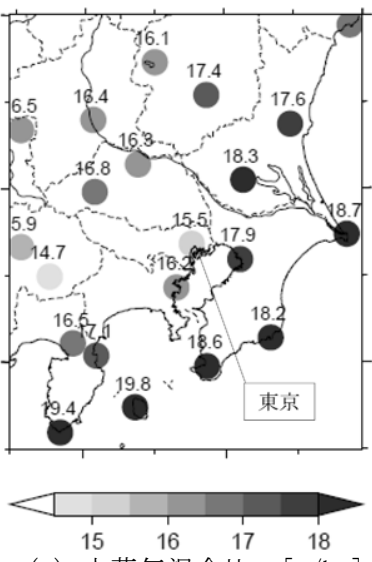

（a）水蒸気混合比 $[\mathrm{g} / \mathrm{kg}]$

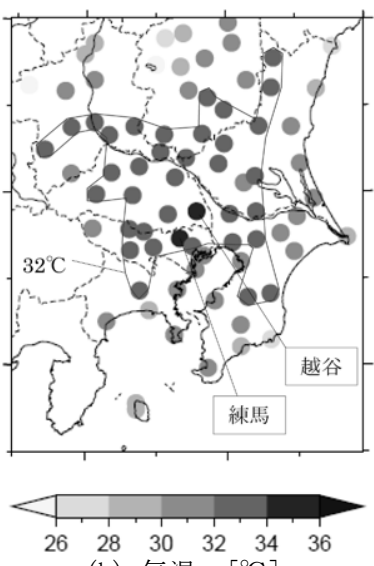

(b) 気温 $\left[{ }^{\circ} \mathrm{C}\right]$

図 2 観測值 (12 時, 地上 2m)

し検証する。ここでは，計算結果および観測結果ともに，対象日 8 日間の単純平均を時刻毎に算出して示している。

12 時における地上の水蒸気混合比および気温について, 観測值を 図 2 に, 解析值を図 3 に示寸。図 2 (a) では混合比をプロットの色と 数值で示した。図 $2(\mathrm{~b})$ では気温 $32^{\circ} \mathrm{C}$ 以上のプロット点の範囲の外形 を細実線で大まかに囲っている。図 2 (b)に示した気温の観測值を見 ると, 内陸の広範囲にわたって高温 $\left(32^{\circ} \mathrm{C}\right.$ 以上）となっている。最 も気温が高い地点は, 都心に近い地域（練馬, 越谷）であり気温は $34^{\circ} \mathrm{C}$ を超えている。図 3(b)に示した気温の解析值では, 都心に近い 地域で高温となる様子を再現している。ただし, 平野部で全体的に 観測よりも気温が約 $1 \sim 2^{\circ} \mathrm{C}$ 低い。これは, 解析された地表面での潜 熱フラックスに対する顕熱フラックスの割合（ボーエン比）を算出 すると, 平野部で約 0.3 程度となっており, 関東平野の夏季の平均 的な観測值 $0.5^{38}$ に比べて小さいことが主因である。平野部で解析 されたボーエン比が小さくなることは, 既報 ${ }^{36)}$ の図 9(a)でも見られ るが, 表面フラックスの計算に使用している粗度長スキーム (Garratt）に起因していると考えられる。気温が全体的に低いこと は，局地循環の強度に影響し，局地循環による水蒸気輸送の再現性 に影響する可能性がある。局所循環の再現性については, 後節にお いて確認する。水蒸気混合比の分布を見ると, 図 2 (a) の観測值では, 太平洋沿岸の観測点（銚子, 勝浦, 館山, 大島, 伊東) で混合比が $18 \mathrm{~g} / \mathrm{kg}$ 以上であるが, 東京湾沿岸（東京, 横浜, 千葉）では, 混合 比が 15〜 $18 \mathrm{~g} / \mathrm{kg}$ となっており太平洋沿岸部よりも少ない。特に, 東 京での水蒸気混合比は $15.5 \mathrm{~g} / \mathrm{kg}$ であり最も低い。藤部 ${ }^{39)}$ によると, 夏季の高温日では, 東京の水蒸気量が近年に増える傾向にあること が見出されているが，周辺の地域と比べると依然として乾燥してい ることを示している。また, 榊原ら ${ }^{401}{ }^{41}$ は, 越谷および小布施を対 象とした観測結果から, 市街地では, $1 \mathrm{~km}$ 程度離れた郊外に比べて 夏季の日中に水蒸気圧が最大で $4 \mathrm{hPa}$ 以上低いことを示した。これは, 水蒸気混合比に換算すると $2.5 \mathrm{~g} / \mathrm{kg}$ 程度少ないことになる。このよ うに, 夏季の日中では, 都市域での水蒸気量が局所的に変化するこ とが知られており, 図 2 (a)では都市が郊外に比べて乾燥している状 況が現れていると言える。図 3 (a) に示した計算結果では, 東京で水 蒸気量が周囲に比べて若干少なくなっており, 上述したような東京 での乾燥傾向が現れている。また, 東京湾沿岸の水蒸気量は, 太平

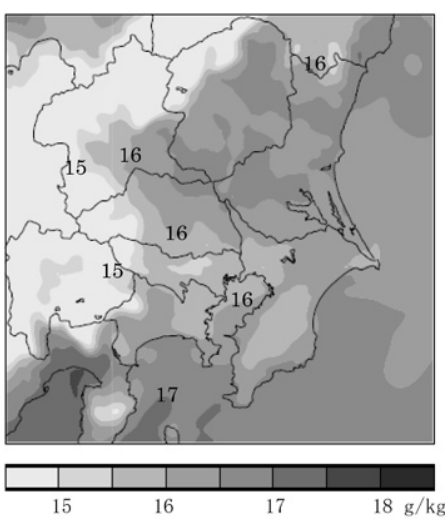

（a）水蒸気混合比 $[\mathrm{g} / \mathrm{kg}]$

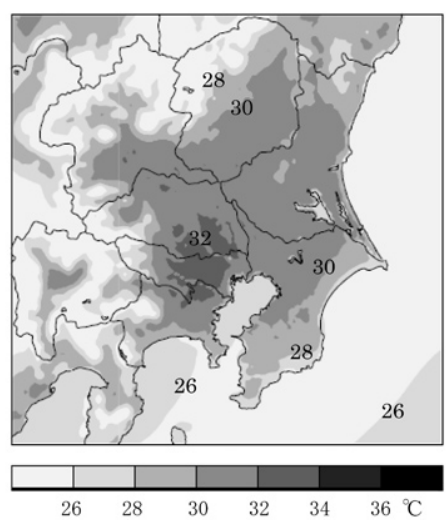

(b) 気温 $\left[{ }^{\circ} \mathrm{C}\right]$
図 3 解析值 (12 時, 地上約 $40 \mathrm{~m}$ )

洋沿岸に比べて少なく, 平野北西部と同等程度になっている。この ように，地上での水蒸気量の分布は，定性的には観測記録と整合し ている。

東京の大手町における水蒸気量の日変化を解析結果と合わせて図 4 に示す。同図では, 水蒸気量のほかに気温, 風向風速も示してい る。観測值では, 10 時前後に風向が急変し, 気温の上昇が緩やかに なっていることから，10 時前後に海風が進入したと考えられる。水 蒸気混合比を見ると,海風が進入したと思われる 10 時以降に急激に 減少し， 15 時頃までに約 $1 \mathrm{~g} / \mathrm{kg}$ 減少した。計算值では 9 時に風向が 南西から南東に変わり海風が進入していると考えられる。計算され た水蒸気量は, 海風の進入後に 12 時までに約 $1 \mathrm{~g} / \mathrm{kg}$ 減少している。 夏季の日中に東京が乾燥する傾向にあることを観測および解析結果 から確認した。乾燥する理由は 3 考えられる。主因は, 都市域で は潜熱放出が少ないためである。2つ目は，日中に混合層が発達す る際に，地上付近の水蒸気が上空に輸送されるためである。もう 1 つは, 海風の反流が上空の乾燥空気を地上に輸送していることも考 えられる。計算值は，観測に比べて海風の進行が約 1 時間程度早い が，水蒸気混合比の時間変化をある程度再現していると言える。た
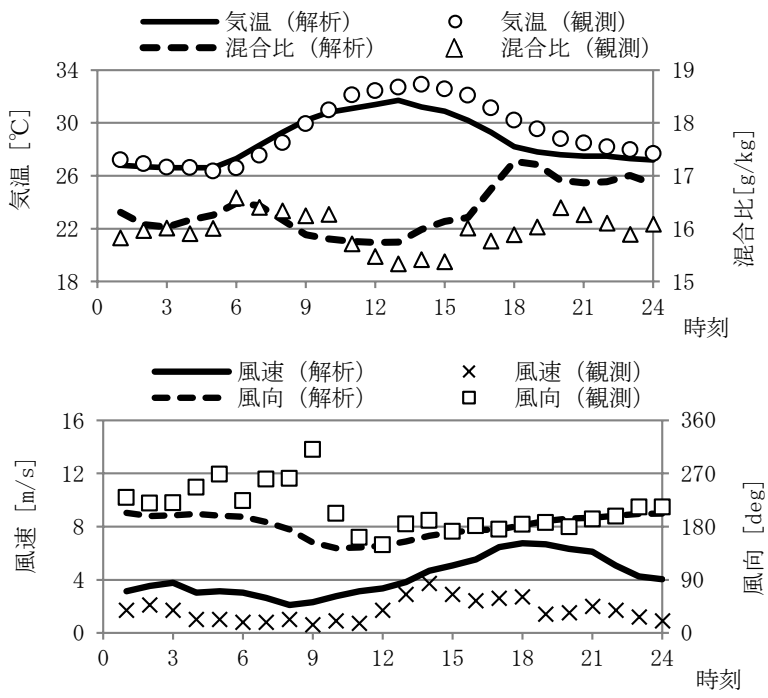

図 4 東京（大手町）における地上気象場の日変化 


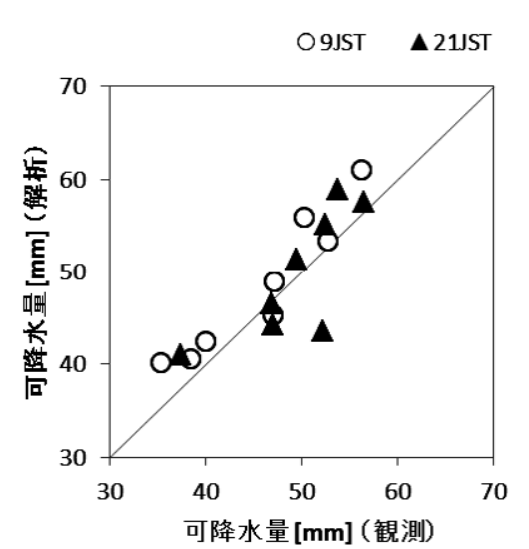

図 5 館野における可降水量

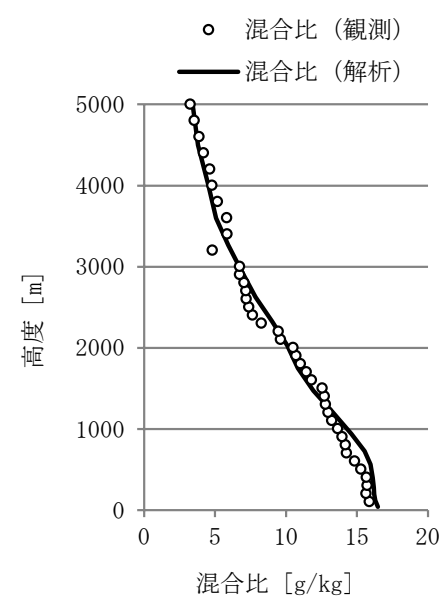

(a) 9 時

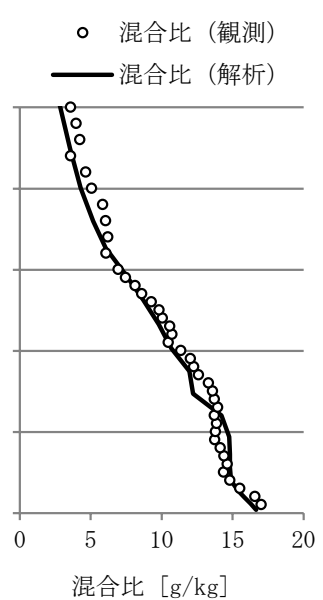

(b) 21 時

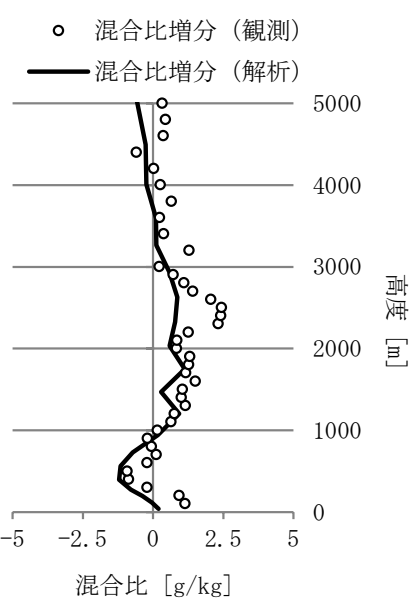

(c) 増分 (21 時-9 時)

図 6 館野における水蒸気混合比の鉛直プロファイル

だし, 計算值は観測に比べて午後以降に低温多湿になっている。こ れは, 前述したように, 計算では平野部で解析された潜熱フラック スに対する顕熱フラックスの比が低いことに起因すると考えられる。

\section{2 水蒸気の鉛直分布}

次に, 関東地方の上空の水蒸気量について確認する。図 5 に検討 対象の各 8 日間における館野での可降水量付䩮 $\mathrm{A}$ を計算值と観測值を 比較して示す。高層観測記録から算出した可降水量は $35.4 \mathrm{~mm}$ から $56.6 \mathrm{~mm}$ まで幅広い值を示す。計算値は日中（9 時）の可降水量を観 測に比べて 8 日間平均で $2.5 \mathrm{~mm}$ 過大評価するが, 21 時は観測との差 は $0.3 \mathrm{~mm}$ であった。図 6 に館野で観測された水蒸気混合比の鉛直プ ロファイルの 8 日間平均值を計算結果と比較して示す。9 時の観測 值では, 高度 $500 \mathrm{~m}$ 以下において水蒸気混合比は高度によらず一定值 を示しており, 混合層を生じている。解析結果では, 9 時における 混合層の高度が約 $700 \mathrm{~m}$ になっており, 観測值に比べると混合層高度 が高い。さらに, 混合層内の水蒸気混合比も観測に比べて高く, こ れらによって日中の可降水量を過大に予測した。21 時のプロファイ ルでは高度 $800 \mathrm{~m}$ から $1700 \mathrm{~m}$ において観測值と計算值が一致しない。 21 時のプロファイルから 9 時のプロファイルを差し引いて求めた水
蒸気混合比の増分を図 6 (c) に示す。観測では, 高度 $1000 \mathrm{~m}$ から $3000 \mathrm{~m}$ の間で水蒸気混合比が $1.5 \sim 2.5 \mathrm{~g} / \mathrm{kg}$ 増加し, それを主因として可降 水量は $3.6 \mathrm{~mm}$ 増加した。解析值における水蒸気の増分を見ると, 高 度 1000 から $3000 \mathrm{~m}$ の間で水蒸気混合比が $1.5 \mathrm{~g} / \mathrm{kg}$ 程度増加し, 可降 水量では $1.3 \mathrm{~mm}$ 増加した。計算による増加量は観測記録よりも少な いものの, 増加する高度は一致している。この高度で水蒸気量が増 加することは, 別の期間における佐々木ら ${ }^{29)}$ の GPS 可降水量の観測 結果でも示されている。この高度で水蒸気が増加する原因は, 日中 の局所循環（谷風・海風）によって山岳域の上空に水蒸気が蓄積さ れ, それが平野部に水平移流し, 平野部の上空を加湿したためであ ると考えられる ${ }^{29)}$ 。本解析結果は水蒸気量に観測との間で不一致が あるものの, 水蒸気輸送の傾向は捉えていると考えられ, 局所循環 による水蒸気輸送を再現する上で深刻な違いではないと判断した。

\section{5. 局地循環による水蒸気輸送}

本章では, 数值計算の結果を中心に, 局所的な循環による水蒸気 輸送について検討寸る。図 7 に，(a) 6 時における可降水量の水平分 布, (b) 15 時における 6 時からの可降水量の増減, (c) 15 時の地上高
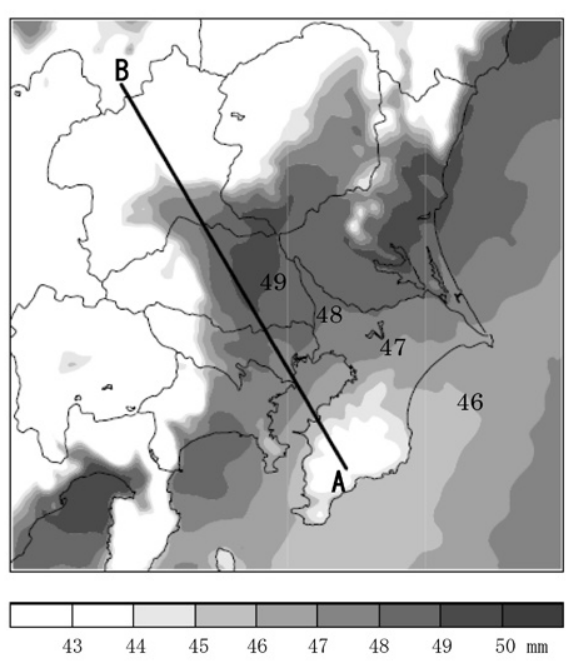

(a) 可降水量 (6 時)

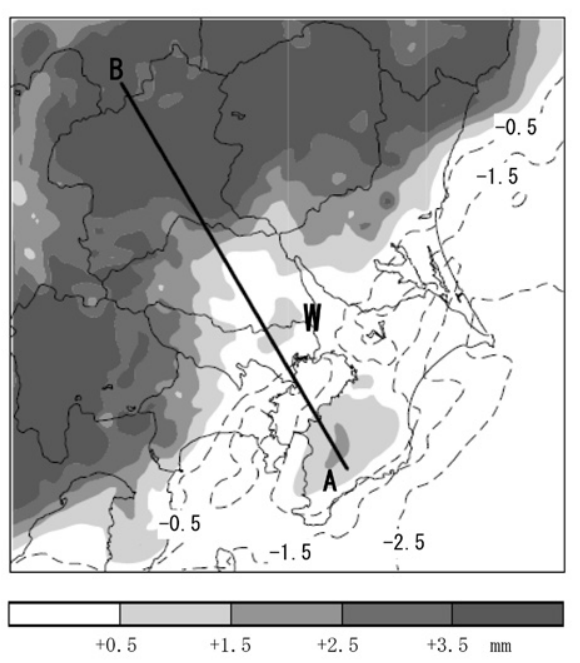

（b） 6 時からの可降水量の増減（15 時）

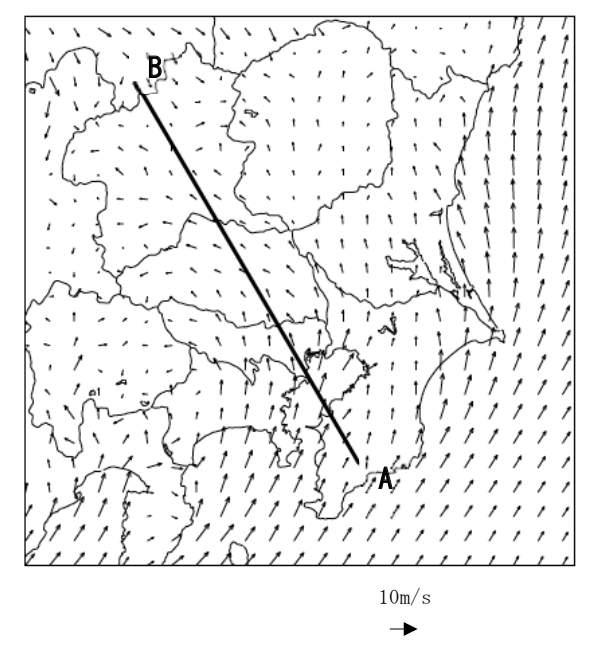

（c）風速ベクトル（15 時）

図 7 可降水量および風速べクトルの分布（解析値） 
さ $40 \mathrm{~m}$ での風速，をそれぞれ示した。図 7 (a) に示した 6 時の可降水 量を見ると, 関東平野の内陸部では $49 \mathrm{~mm}$ を超えている。海上では鹿 島灘沖の可降水量が比較的に多いが，これは関東平野から流出した 分であり, 海上および沿岸部での可降水量は概ね内陸よりも少ない。 山岳ではさらに可降水量が少なく $44 \mathrm{~mm}$ 以下になっている。海上およ び沿岸部での可降水量が内陸よりも少ないことは, 沿岸部の地上で の水蒸気混合比が多いこと（図 2）と整合しないように見える。し
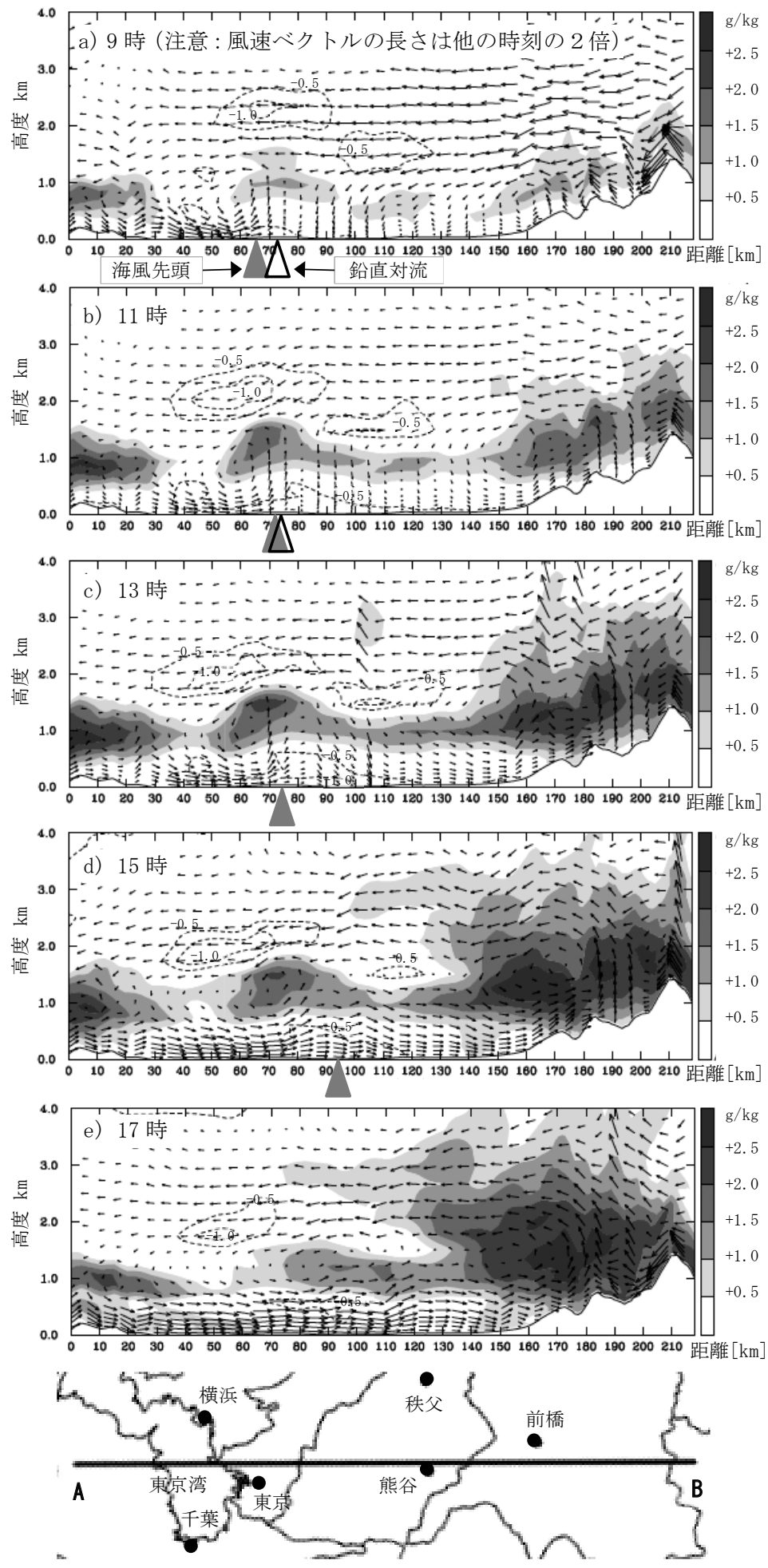

図 8 断面 A-B における水蒸気混合比の鉛直分布（解析值）
かし, 佐々木ら ${ }^{29)}$ は, 夏季の静穏日における G P S 可降水量を調べ, 沿岸部および島嶼において地上比湿が内陸に比べて多くても，それ らの地域で必ずしも可降水量が内陸に比べて多くなるわけでないこ と明らかにしている。

図 7 (c)に示した 15 時における風速ベクトルをみると平野部では 広い範囲で風向が南寄りになっており, 広域海風が発生している。 図 7 (b) に示した 15 時における 6 時からの可降水量の増減を見ると, 山岳域および関東平野の北部で可降水量が大きく増加して いる。これは, 広域海風と谷風によって平野部の水蒸気が 山岳域に向かって輸送され続けていることによる。山岳域 以外では, 東京都心の北部に可降水量が $0.5 \sim 1 \mathrm{~mm}$ 増加して いる領域がある (図 $7(\mathrm{~b})$ の)。その領域は, 山岳域から広 がる可降水量の増加領域からは孤立しており，山岳域とは 異なるプロセスで増加していると考えられる。領域Wでの 増加量は山岳域での増加量に比べると小さく, 増加してい る地域の範囲も広くはない。ただし, 比較的に海に近い地 域では, 地形の起伏がある房総半島を除くと可降水量がほ とんど変わらないか減少していることに比べると特徴的で ある。

可降水量の増加領域（図 7 (b) のW 領域）を通り海風の風 向に沿った断面 A-B（図 7 の黒実線）における水蒸気の分 布を図 8 に時系列で示寸。同図では，6 時を基準とした水 蒸気混合比の増加域を灰色コンタで表し, 減少域は点線の
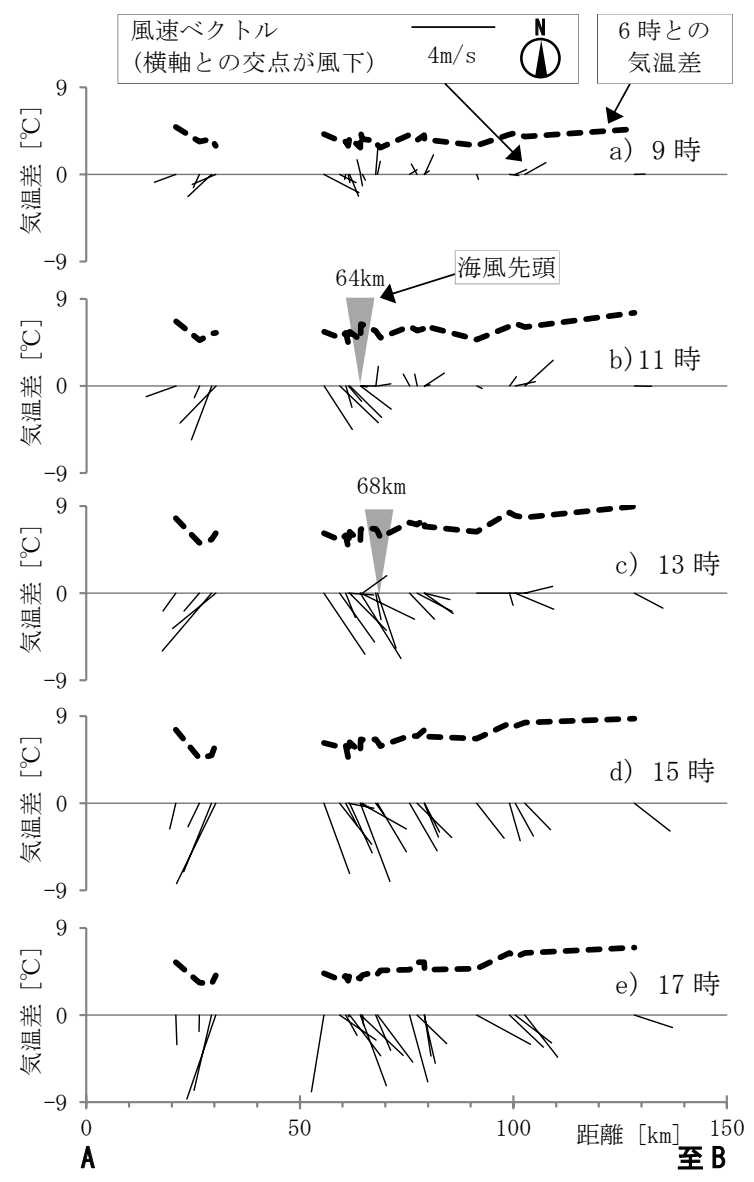

図 9 断面 $\mathrm{A}-\mathrm{B}$ における地上風速（観測值） 
等值線で示した。下端横軸の数字は A 地点 からの距離である。また, 各図の下端には, 海風の先頭位置を塗り潰し三角形で示した。 また，都市高温域で鉛直対流が確認できる 時刻には, その位置に白抜き三角形をつけ た。海風の先頭位置は, 地上 $500 \mathrm{~m}$ 程度の仮 温位の水平勾配および鉛直風速の強弱を判 断基準とし主観的に決定した (図省略)。ま た，鉛直対流の位置は，地上における仮温 位, 風速ベクトルの分布, および地上 $500 \mathrm{~m}$ 程度の鉛直風速の強弱を判断基準とした (図省略)。まず, 海風の進行状況を確認す る。9 時には海風の先頭は東京 (大手町, 横軸 $65 \mathrm{~km}$ ）を通過した。この時刻には, 東 京都と埼玉県の境に地上の高温に伴う鉛直 対流が発生していた。海風は平均時速 $3 \mathrm{~km} / \mathrm{h}$ 程度で進んだが， 11 時 過ぎに鈆直対流と融合すると進行が遅くなり，13 時までほぼ停滞し た。その後, 進行速度は $10 \mathrm{~km} / \mathrm{h}$ 程度に早まり, 山岳地まで繋がる広 域海風に移行した。海風先頭の上昇気流の到達高度は, 地上高温域 での鉛直対流を融合して 14 時に最大で高度 $1.8 \mathrm{~km}$ に達した。海風の 上空の風速ベクトルを見ると, どの時間帯においても海風の反流を 確認できる。海風の後方は反流に伴う下降流があり循環を形成して いる。

次に, 水蒸気の鉛直分布について見ると, 9 時には, 地上高温に 伴う鉛直対流の上端部で水蒸気混合比が増加しているが, 海風先頭 における上昇気流の上端部では増加は目立たない。11 時に, 鉛直対 流と海風の上昇気流が融合すると(以降では単に海風と称す), 横軸 距離 60〜 70km の上空 $1.4 \mathrm{~km}$ 付近で水蒸気混合比が急速に増加する。 一方で, 地上付近は水蒸気混合比が減少しており, 海風先頭での上 昇気流は地上付近の水蒸気を上空に輸送していることが分かる。ま た, 海風循環の下降域では, 上空の乾燥空気が下方に輸送され, 水 蒸気混合比が減少した。海風先頭での上昇気流は 14 時まで時間とと もに強まり, それに加えて海風の進行が遅いために, 水蒸気が上空 で蓄積している。海風先頭の上空における水蒸気混合比は 14 時に極 大となり（横軸距離 $70 \mathrm{~km}$ あたり), 6 時に比べて $2 \mathrm{~g} / \mathrm{kg}$ 増加した (図 省略)。15 時に広域海風に移行すると海風による鉛直循環が目立た なくなり, 海風先頭での強い上昇気流の下にあった乾燥域は解消し たが上空の水蒸気は残ったために, 可降水量の増加量は 15 時に最大 となった。その後, 海風循環によって上空に蓄積された水蒸気は, 上空風によって移流しながら拡散希釈された。

海風の進行方向の前方では, 平野部（横軸 $100 \sim 140 \mathrm{~km}$ ) の上空 $1 \mathrm{~km}$ 程度に 6 時から比べて水蒸気量が増加する層がある(図 $8(\mathrm{a}) \sim 8(\mathrm{c})$ )。 これは, 鉛直対流によって地上付近の水蒸気が混合層上部に輸送さ れたと考えられるが, 13 時の増加量は $1 \mathrm{~g} / \mathrm{kg}$ 程度である(図 8 (c))。 山岳域では, 広域海風と谷風によって輸送された水蒸気が蓄積し, 17 時には 6 時に比べて $3 \mathrm{~g} / \mathrm{kg}$ 以上も増加した場所がある(図 $8(\mathrm{e})$ )。

海風の進行状況を観測記録から確認する。図 9 に断面 $\mathrm{A}-\mathrm{B}$ （図 7 の黒実線) 上で観測された地上気温および地上風速ベクトルを示す。 観測記録は大気污染常時監視局のデータであり, 断面 A-B から距離 $5 \mathrm{~km}$ 以内にある観測地点のデータを, A-B 断面に直交投影した位置に
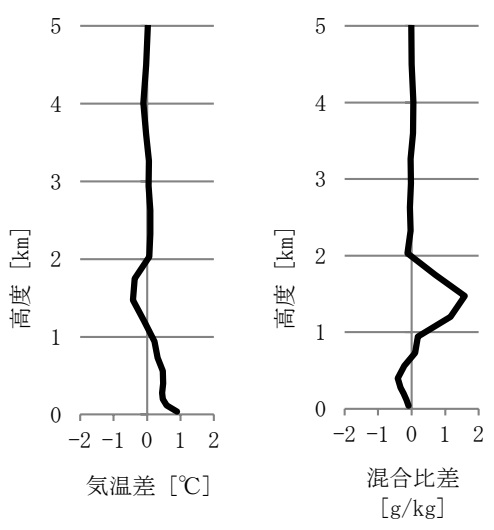

図 11 東京 15 時における鉛直分布の差 (基本ケース-都市なしケース)

プロットした。地上気温は 6 時からの気温差である。風速べクトル の長さは風速を表し, 横軸との交点が風下を表し, 横軸より上に垂 直の伸びている場合は北風である。図中には海風の先頭位置を三角 形で示している。海風の先頭位置の判断基準は, 気温差の増加が穏 やかになったこと, および風速べクトルの長さと向きである。眓 9 を見ると，9時には海風の先頭は判別が付かないが，遅くとも 11 時 には東京（横軸 $64 \mathrm{~km}$ ，大手町あたり）を通過し，13 時までの平均時 速は約 $2 \mathrm{~km} / \mathrm{h}$ である。その後, 海風の先頭位置の判別が難しくなる が，13 時から進行速度が速まり，その後は谷風と一体となっている ように見える。総じて, 図 8 に示した計算結果は地上観測記録から みた海風の進行状況をよく再現していると言える。

\section{6. 都市効果}

\section{1 可降水量}

前節では, 海風の進行速度が遅いために都市部の上空に水蒸気が 蓄積される可能性を示唆した。海風の進行速度が遅くなる要因とし て, Yoshikado ${ }^{42)}$ は都市域の高温に起因する局所的な低気圧が, 都市と内陸部との間に逆圧力勾配を形成し, 海風の進行を阻害して いることを理想化した 2 次元計算結果から指摘している。さらに Kusaka ${ }^{25)}$ は, それを現実的な首都圈の土地利用形態を考慮した 3 次元計算でも確認している。また, 大岡ら ${ }^{43}$ はメソスケールモデル を用いて海風の平均運動エネルギー収支を検討し, 逆圧力勾配だけ でなく, 都市域では地表面摩擦も海風の平均運動エネルギーを大き く消費していることを示している。つまり, 都市域が存在すること により海風の進行が阻害され, 都市域の上空に水蒸気が蓄積された 可能性がある。ただし，これまで示した海風の停滞位置は標高 $50 \mathrm{~m}$ 程度の丘になっており, この地形によって海風が停滞した可能性も ある。ここでは, 都市が存在することによって, 海風の進行やそれ に伴う上空での水蒸気蓄積に対してどの程度影響したか, 数值計算 に基づいて検討する。図 10 に 15 時における可降水量を, 基本ケー スから都市なしケースを差し引いて示す。その結果は, 都心部にお いて可降水量が増加していることを示しており, 増加量は約 $1 \mathrm{~mm}$ で あった。この可降水量が増加する領域は, 図 7 (b) に示した領域W と ほぼ一致しており, 領域 Wにおける可降水量の増加量 $0.5 \sim 1 \mathrm{~mm}$ は, 都市効果による増加量と同程度である。 
図 10 に示した都市効果による可降水量の増加量 $1 \mathrm{~mm}$ を, 館野にお ける日中の可降水量の増加量 $3.6 \mathrm{~mm}$ (図 6 (c) の観測值) と比べると $1 / 4$ 程度である。また, この都市効果による可降水量の増加 $1 \mathrm{~mm}$ が 確認できるのは日中の数時間程度である。つまり, 都市効果による 可降水量の増加は, 時間的なスケールは短く, 増加量としてもかな り限定的であった。しかし, 図 10 に示した都心での可降水量の増加 領域の位置および大きさは, Fujibe ${ }^{11}$ が統計的に検出した, 都心で 降水量が増加している地域と類似していることは注目に値する。

一方, 図 10 では, 埼玉県で可降水量が減少する地域がある。これ は都市なしケースにおいて海風が到達した位置と一致しており, 都 市がなければ輸送された水蒸気量を示している。また, 都市から離 れた山岳域でも可降水量の増減が見られる。これについての詳細は 不明であるが, 山岳域では降雨が生じており, それに伴う予測困難 性が現れていると考えられる。

\section{2 大気安定度}

東京での 15 時における気温と水蒸気混合比の鉛直プロファイル を, 基本ケースから都市なしケースを差し引いて図 11 に示す。同図 を見ると, 高度 $1 \mathrm{~km} \sim 2 \mathrm{~km}$ において基本ケースの気温は都市なしケー スに比べて低いものの, 水蒸気混合比が多くなっている。上空の湿 度が高いと大気は不安定化し易い。ここでは, 都心部の上空で増加 した水蒸気が大気安定度に与える影響について検討する。大気安定 度の指標として, K指数 (KI), シュワルター安定指数 (SSI), 対流 有効位置エネルギー（CAPE）を用いた。それぞれの指標の算出方法 は付録 B1〜B3 に示した。また, 指標を計算するのに用いる鉛直プロ ファイルは, 東京における 15 時を計算結果である。Weckwerth ら ${ }^{44)}$ は, 米国フロリダ半島で実施された観測プロジェクト CaPE のデータ を用いて, 積乱雲を生成した水平ロールの大気安定度を評価した。 その際に, 評価に使う観測值に, 水平ロールに伴う上昇域で計測し たデータを用いないと, 大気の不安定度を過小評価するとしている。 ここでは, 都市域で局所的に蓄積した水蒸気による大気安定度への 影響を評価するために, 都市域（東京）での鉛直プロファイルを使 用した。各指標の対象 8 日間の平均值を表 4 にまとめて示す。ただ し, CAPE は大気が潜在不安定 (latent instability) な状態でない と算出できないが, 対象日 (8 日間) の中で 2006 年 8 月 3 日は, 都 市なしケースで潜在不安定ではなかったため CAPE を算出できなか った。よって, CAPEについては残りの 7 日間について平均を算出し た。CAPE およびK 指標（KI）は正值が大きいほど対流活動が活発に なり雷雨が発生し易くなる。または, シュワルター安定指数（SSI） は負值の絶対值が大きいほど不安定度が高いことを示す。

表 4 を見ると, 都市を考慮した基本ケースおよび都市なしケース ともに, K 指標 (KI) は負值であり, シュワルター安定指数 (SSI) は正值となり, 大気は安定であると判定されている（付表 B1, B2）。 CAPE を見ると両ケースともに「やや不安定」となっている(付表 B3)。 これらの指標からは, 本研究における対象日（夏季静穏日）は, 平 均的には, 大気が安定な状況であったことが判る。ただし, CAPE は, 都市を考慮した基本ケースの方が, 都市なしケースよりも対象日平 均で約 $140 \mathrm{~J} / \mathrm{kg}$ 増加し, 大気が不安定になる方向に変化した。

\section{3 先行研究との比較}

本研究での検討対象日は, 夏季の静穏日であり, 平均的には大気 の成層状態が安定していた。そのような日には, 都市がある場合,
表 4 東京における大気安定度の指標

\begin{tabular}{cccc}
\hline & $\begin{array}{c}\mathrm{KI} \\
{\left[{ }^{\circ} \mathrm{C}\right]}\end{array}$ & $\begin{array}{c}\mathrm{SSI} \\
{\left[{ }^{\circ} \mathrm{C}\right]}\end{array}$ & $\begin{array}{c}\mathrm{CAPE} \\
{[\mathrm{J} / \mathrm{kg}]}\end{array}$ \\
\hline 基本ケース & -13.4 & 2.2 & 571 \\
都市なしケース & -16.4 & 4.3 & 435 \\
(基本ケース)-(都市なしケース) & 3.0 & -2.1 & 136 \\
\hline
\end{tabular}

海風先頭の上昇気流と地上高温に伴う鉛直対流が相互作用すること で, 海風先頭の上昇気流が強化される。その強化された上昇気流は, 下層の水蒸気を汲み上げ, 都市域の可降水量を増加させる可能性が あることを数值計算に基づいて示した。しかし，可降水量が増加す る時間的なスケールは短く, 増加量としてもかなり限定的であった。 妹尾ら ${ }^{22)}$ は, 関東地方での夏季南風晴天日を対象として, 詳細な 人工排熱量 (顕熱, 潜熱) を導入した数值計算を実施し, 都市域に おける水蒸気の動態を調べている。彼らによると，人工排熱を無視 したケースに比べて, 人工排熱を全て顕熱としたケースでは, 東京 都心の北部において可降水量が増える地点があることを示している。 この主因として, 人工顕熱によって海風等による収束が強まったこ とを挙げている。また，人工排熱量（顕熱，潜熱）を詳細に考慮す ると, 当該地域での可降水量の増加量が減るとしている。彼らの結 果を参考にすると，本研究では人工排熱を全て顕熱として扱ってい るので, 顕熱と潜熱の割合を詳細に考慮した場合に比べて, 都市域 での可降水量の増加量を過大に評価している可能性がある。

Matheson ら $^{23)}$ は, 複数の強雨事例に関する数值計算に基づいて, 水蒸気の動態について検討している。彼らの結果と比較すると, 都 市域の上空で水蒸気が増加し, 下層で乾燥する事例があることは本 研究の結果と共通する。また, Matheson ら $^{23)}$ では, 都市域の上空で 増加した水蒸気が, 都市域に降雨をもたらしたとしている。しかし, 都市の上空で増加した水蒸気の起源については本研究と解釈が異な る。Matheson ら ${ }^{23)}$ の事例では, 都市域に北側から吹き込む空気塊に 起源があるとしており，都市域の下層から吸い上げられるとしてい る本研究とは異なる。このように, 都市域上空における水蒸気の輸 送経路については, 事例毎に慎重な判断が求められる。

一方, 日下ら ${ }^{21)}$ の強雨事例研究では, 1 事例のみに関する結果で あるものの, ヒートアイランドに伴う下層収束によって水蒸気が集 積する様子 (GPS 可降水量の増加) は確認できなかったとしている。 その理由として, 日下ら ${ }^{21)}$ の事例では, 平野スケールでの下層収束 があり, さらに大気の成層状態が不安定であったために, ヒートア イランドの影響が主因に成りにくかったとしている。つまり, 本研 究で示した都市効果（都市域での可降水量の増加）は，大気の成層 状態が比較的に安定な, 夏季静穏日に限定して顕在化するものであ る可能性がある。ただし, 日下ら ${ }^{21}$ が課題として挙げているように, 降雨に対する都市効果を判断するには, 様々な事例について, さら なる積み重齐が不可欠である。

\section{7. まとめ}

（1）メソスケールモデルを用いて夏季静穏日の関東地方を対象 とした数值計算を実施した。可降水量を定量的に良く再現す るとともに, 海風の進行速度の変化など局所循環における風 系の特徵的な傾向を良く再現した。 
（2）海風の前面にある上昇流は下層の水蒸気を上空に輸送する が, 海風の進行中は可降水量に変化はない。海風の進行速度 が都市域通過後に遅くなると, 海風先頭の上空に水蒸気が蓄 積し, 可降水量が増加する。この増加量は都市が存在するこ とに起因する増加量と一致する。

（3）（2）に示した都市域での可降水量の増加は，空間的・時間的 なスケールは小さく，増加量としてもかなり限定的である。 また, この可降水量の増加は, 夏季静穏日に限定的に顕在化 する現象である可能性がある。

（4）夏季静穏日の大気安定度指標（SSI，KI）を検討対象日で平 均すると, 都市を考慮したケースおよび都市なしケースとも に, 大気は安定であった。また, 有効刘流位置エネルギ CAPE では, 都市を考慮したケースは, 都市なしケースに比べて, 増加した。

\section{謝辞}

2 名の查読者には有益なご意見をいただき，本稿を改良するのに とても役立ちました。記して謝意を示します。本研究は科研費基盤 研究 (S) (研究課題番号 : 24226013, 研究課題名 : 都市環境防災のた めの高解像度気象情報予測プラットフォームの構築, 代表 : 大岡龍 三）の助成を受けて実施した。

\section{付録 $\mathrm{A}$ 可降水量}

可降水量 Pは, 式(付 A1) から算出した。

$$
P=\int_{p_{O}}^{p_{s f c}} \rho s d p \cdots \text { (付 } \mathrm{A} 1 \text { ) }
$$

$p ， p_{s f c} ， p_{0}$ は，それぞれ気圧，地表面気圧，大気上端を示す。 $\rho$ は空気密 度, $s$ は水蒸気の比湿を表す。大気上端は, 観測值では高層観測記録における 最高高度とした。解析值ではモデル最上端高度（30hPa）とした。

\section{付録 B 大気安定度の指標}

\section{(1) $\mathrm{K}$ 指数 (KI)}

$K$ 指数（KI）は, 式(付 B1) から算出する。 $K$ 指数における大気安定度の目 安を付表 B1 に示す。

$$
K I=T_{850}-T_{500}+T_{d 850}-\left(T_{700}-T_{d 700}\right) \cdots \text { (付 B1) }
$$

ただし， $T_{850}, T_{700}, T_{500}$ は $850 \mathrm{hPa}, 700 \mathrm{hpa}, 500 \mathrm{hPa}$ における気温であ り, $T_{d 850}, T_{d 700}$ は $850 \mathrm{hPa}, 700 \mathrm{hpa}$ における露点温度である。

(2) シュワルター安定指数（SSI）

シュワルター安定指数（SSI）は, 式(付 B2)から算出する。シュワルター 安定指数における大気安定度の目安を付表 B2 に示す。

$$
S S I=T_{500}-T^{*}{ }_{500} \cdots \text { (付 B2) }
$$

ただし， $T_{500}$ は $500 \mathrm{hPa}$ における気温であり， $T^{*} 500$ は $850 \mathrm{hPa}$ の空気塊を 持ち上げ凝結高度 $^{\text {注 } 1)}$ まで持ち上げ，そこから湿潤断熱的に $500 \mathrm{hPa}$ まで持ち
上げたときの温度である。

(3) 対流有効位置エネルギ（CAPE）

対流有効位置エネルギ（CAPE）は，自由対流高度注 1) を超えて持ち上げられ た空気塊が自らの浮力により得られるエネルギの総量であり, 式(付 B3)から 算出する。対流有効位置エネルギにおける大気安定度の目安を付表 B3 に示す。 $C A P E=\int_{p_{L N B}}^{p_{L F C}} R\left(T_{v p}-T_{v a}\right) d \ln p \cdots$ (付 B3)

$p, p_{L F C}, p_{L N B}$ は，それぞれ気圧，自由対流高度，中立浮力高度注 1)である。 $R$ は乾燥気体定数である。 $T_{v p}, T_{v a}$ は, それぞれ上昇空気塊の仮温度注 ${ }^{1)}$, 周 囲の仮温度である。CAPE は NCAR 提供が提供している可視化プログラム RIP4 （Read/Interpolate/Plot version4）の機能を利用して算定した。具体的には, 高度 $3000 \mathrm{~m}$ 以下で，相当温位 ${ }^{1)}$ が最大となる高度を基準とした上下約 $250 \mathrm{~m}$ の層での相当温位の平均值を求め, その相当温位に基づいて CAPE を算出した。

注

注 1) 仮温度とは湿潤空気に対して乾燥空気がもつべき仮想的な温度であり， 水蒸気混合比 $q$, 乾燥空気の温度 $T$ を用いて $(1+0.61 q) T$ と表す。相当温位と は空気塊の含まれる水蒸気が全て凝結するまで断熱的に上昇させ，その後 に乾燥させたまま基準気圧（通常は 1000hPa）の高度に戻したときの温度 である。また, ある空気塊を上昇させたときに, 水蒸気が飽和し凝結し始 める高度を持ち上げ凝結高度という。さらに空気塊を上昇させ，その空気 塊が持つ相当温位と周囲の飽和相当温位が同值になった高度は自由対流高 度である。自由対流高度を超えると, その空気塊は浮力により上昇するが， その浮力が無くなる高度を中立浮力高度という。

\section{参考文献}

1）国土交通省：都市部で顕在化する「内水汇濫」，水害対策を考える，3 章, 3-3-2, 2011.12, http://www.mlit.go.jp/river/pamphlet_jirei/ bousai/ saigai/kiroku/suigai/suigai.html（閲覧日 2013/6/7）

2）真木雅之，三隅良平，中谷剛，鈴木真一，山田芳則，足立ア木ロ，中村功, TOMACS メンバー: 気候変動に伴う極端気象に強い都市創り-TOMACS国際シンポジウム 都市と極端気象, pp.4-9, 2012.10

3）島村誠：列車を災害から守る-JR 東日本における気象情報の活用-，国際シ ンポジウム 都市と極端気象, pp.40-41, 2012.10

4）大塚清敏：建設現場における気象情報の活用可能性について-ユーザーの 立場からの検討事例-，国際シンポジウム 都市と極端気象，pp.42-43， 2012.10

5）松下くるみ，三隅良平，前坂剛，岩波越：東京都における内水氾濫被害の 要因分析，防災科学技術研究所研究報告，第 80 号, pp.1-20, 2012.11

6) Shepherd J. M.: A Review of current investigations of urban-induced rainfall and recommendations for the future, Earth Interactions, Vol.9, Issue 12 , pp.1-27, 2005.8

7) Huff F. A., Changnon S. A. Jr.: Precipitation modification by major urban areas, Bulletin American Meteorological Society, Vol.54, No.12, pp.1220-1232, 1973.12

8) Bornstein R., Lin Q.: Urban heat islands and summertime convective thunderstorms in Atlanta: three case studies, Atmospheric Environment, Vol.34, pp.507-516, 2000

9) Dixon P. G., Mote T. L.: Patterns and Causes of Atlanta's urban heat island-initiated precipitation, Journal of Applied Meteorology, Vol.42, No.9, pp.1273-1284, 2003.9
付表 B1 K指数 $\mathrm{KI}$ の目安

\begin{tabular}{cc}
\hline 範囲 $\left[{ }^{\circ} \mathrm{C}\right]$ & 目安 \\
\hline 15 以下 & 雷雨可能性なし \\
$15 \sim 20$ & 雷雨可能性 $20 \%$ \\
$20 \sim 25$ & 雷雨可能性 $20 \sim 40 \%$ \\
$25 \sim 30$ & 雷雨可能性 $40 \sim 60 \%$ \\
$30 \sim 35$ & 雷雨可能性 $60 \sim 80 \%$ \\
$35 \sim 40$ & 雷雨可能性 80 $90 \%$ \\
40 以上 & 雷雨可能性ほぼ $100 \%$ \\
\hline
\end{tabular}

付表 B2 ショワルター安定指数 SSI の目安

\begin{tabular}{cc}
\hline 範囲 $\left[{ }^{\circ} \mathrm{C}\right]$ & \multicolumn{1}{c}{ 目安 } \\
\hline 0 以上 & 安定 \\
$0 \sim-3$ & 中程度に不安定 \\
$-3 \sim-6$ & 非常に不安定 \\
-6 以下 & 極度に不安定 \\
\hline
\end{tabular}

付表 B3 対流有効位置エネルギーCAPEの目安

\begin{tabular}{cc}
\hline 範囲 $[\mathrm{J} / \mathrm{kg}]$ & \multicolumn{1}{c}{ 目安 } \\
\hline 0 以下 & 安定 \\
$0 \sim 1000$ & やや不安定 \\
$1000 \sim 2500$ & 中程度に不安定 \\
$2500 \sim 3500$ & 非常に不安定 \\
3500 以上 & 極端に不安定 \\
\hline
\end{tabular}


10) Shepherd J. M., Burian S. J.: Detection of urban-induced rainfall anomalies in a major costal city, Earth Interactions, Vol.7, Issue 4, pp.1-17, 2003.4

11) Fujibe F., Togawa H., and Sakata M.: Long-term Change and Spatial Anomaly of Warm Season Afternoon Precipitation in Tokyo, SOLA, Vol.5, pp.17-20, 2009.5

12）佐藤友徳, 寺島司, 井上忠雄, 木村富士男：東京都市域における夏期の降 水システムの強化, 天気, Vol.53, No.6, pp.479-484, 2006.6

13）高橋日出男, 中村康子, 鈴木博人：東京都区部における強雨頻度分布と 建築物高度の空間構造との関係，地学雑誌, Vol.120, No.2, pp.359-381, 2011.4

14) Kusaka H., Kimura F., Nawata K., Hanyu T., Miya Y.: The Chink in the Armor: Questioning the Reliability of Conventional Sensitivity Experiments in Determining Urban Effects on Precipitation Patterns, Proceedings of the Seventh International Conference on Urban Climate, Yokohama, B12-2, 2009

15）小倉義光, 奥山和彦, 田口昌彦:SAFIR で観測した夏季の関東地方におけ る雷雨と大気環境: I 雷雨活動の概観と雷雨発生のメカニズム, 天気, Vol.49, No.7, pp.541-553, 2002.7.

16）下重亮，仲吉信人，神田学：都市の幾何形状と地形によって生じる海風 の収束が東京の夏季局地的集中豪雨発生に及ぼす影響, 水工学論文集, 第 53 巻, pp.277-282, 2009.2

17）下重亮，仲吉信人，神田学：都市要因を考慮した夏季関東における都市 型集中豪雨の多事例解析, 水工学論文集, 第 54 巻, pp.349-354, 2010.2

18）相馬一義, 田中賢治, 砂田憲吾, 末次忠司, 坪木和久, 榊原篤志, 茂木耕 作：2008 年に東京都雑司が谷付近で発生した局地的大雨一都市加熱が与 えた影響，土木学会論文集 B1(水工学)，Vol.68，No.4，pp.I_403-I_408， 2012.

19）伊藤洋太郎, 茂木耕作, 相馬一義, 萬和明, 田中賢治, 池淵周一: 詳細な 陸面過程を組み込んだ雲解像モデルによる練馬豪雨に対する都市の影響 評価, 水工学論文集, 第 50 巻, pp.385-390, 2006.2

20）神田学, 石田知礼, 鹿島正彦, 大石哲：首都圈における局所的対流性豪雨 と GPS 可降水量の時空間変動-1997 年 8 月 23 日の集中豪雨の事例解析-, 天気, Vol.47, No.1, pp.7-15, 2000.1

21）日下博幸, 羽入拓朗, 縄田恵子: GPS 可降水量に着目した局地豪雨の事 例解析-2000 年 7 月 4 日に東京で観測された事例-, 地理学評論, Vol.83, No.5, pp.479-492, 2010

22）妹尾泰史, 神田学, 木内豪, 萩島理: 潜熱割合を考慮した人工排熱時空間 分布の推計と局地気象に対する影響, 水工学論文集, 第 48 巻, pp.169-174, 2004.2

23) Matheson M. A., Ashie Y.: The effect of changes of urban surface on rainfall phenomenon as determined by a non-hydrostatic mesoscale model, Journal of the Meteorological Society of Japan, Vol.86, No.5, pp.733-751, 2008.10

24）東京都環境局：ヒートアイランド対策ガイドライン, pp.1-26, 2005.7

25) Kusaka H., Kimura F., Hirakuchi H., Mizutori M.: The effects of land-use alternation on the sea breeze and daytime heat island in the Tokyo metropolitan area, Journal of the Meteorological Society of Japan, Vol.78, No.4, pp.405-420, 2000.8
26）ヒートアイランド監視報告 (平成 16 年夏季・関東地方)，気象庁, 2005.3 27）金相琟，村上周三，持田灯，大岡龍三，吉田伸治：数值気候モデルによる 都市化がもたらす関東地方の気候変化のメカニズムの解析, 日本建築学 会計画系論文集, No.534, pp.83-88, 2000.8

28）藤部文昭，瀬古弘，小司禎教：関東平野における夏季高温日午後の降水 分布と地上風系との関係, 天気, Vol.50, No.10, pp.777-786, 2003.10

29）佐々木太一, 木村富士男: GPS 可降水量からみた関東地方における夏季 静穏日の水蒸気量の日変動, 天気, Vol. 48, No.2, pp.65-74, 2001.2

30) Grell G. A., Dudhia J., Stauffer D. R.: A Description of the Fifth-Generation Penn State/NCAR Mesoscale Model (MM5), NCAR TECHNICAL NOTE, NCAR/TN-398+STR, 1995.6

31）川本陽一,大岡龍三：MM5 を用いた都市気候解析モデルの構築 (その 1) 地表面パラメータ設定の改良,及び人工排熱影響の組み込み, 日本建築学 会環境系論文集, Vol.73, No.631, pp.1125-1132, 2008.9

32）資源環境技術総合研究所環境影響予測部：都市における夏季高温化対策 技術の評価方法の開発，環境影響予測部研究資料, pp.135-138, 1997

33）足永靖信，田中稔，山本亨，田中明美：冷熱源機器の導入割合を考慮した 空調システムおよび関連機器の地域排熱量に関する研究, 空気調和・衛生 工学会論文集, No.86, pp.77-86, 2002.7

34）足永靖信，田中稔，山本亨：事務所建物の空調システムの排熱特性に関 する研究, 空気調和・衛生工学会論文集, No.75, pp.89-97, 1999.10

35) Skamarock W. C., Klemp J. B., Dudhia J., Gill D. O., Barker D. M., Wang W., Powers J. G.: A Description of the Advanced Research WRF Version 2, NCAR TECHNICAL NOTE, NCAR/TN-468+STR, 2005.6

36) 山中徹，大岡龍三: 2005 年 8 月 15 日関東に発生した短時間強雨をもたら した大気安定度に対する境界層パラメタリゼーションの感度分析, 日本 建築学会環境系論文集, Vol.77, No.674, pp.303-312, 2012.4

37) Parrish D. F., Derber J. C.: The National Meteorological Center's Spectral Statistical Interpolation analysis system, Monthly Weather Review, Vol.120, pp.1747-1763, 1992.8

38) Gamo M.: Seasonal change of the mixing layer structure at Tsukuba, Journal of the Meteorological Society of Japan, Vol.63, No.1, pp.60-74, 1985.2

39）藤部文昭：東京都心における高温日の湿度の経年変化, 天気, Vol.49, No.6, pp.473-476, 2002.6

40）榊原保志：越谷市南東部における市街地と水田域の水蒸気圧差の特徴, 天気, Vol.42, No.6, pp.355-361, 1995.6

41）榊原保志：長野県小布施町における市街地と郊外の水蒸気圧差の特徴, 天気, Vol.48, No.3, pp.151-158, 2001.3

42) Yoshikado H.: Numerical Study of the Daytime Urban Effect and Its Interaction with the Sea Breeze, Journal of Applied Meteorology, Vol. 31, pp.1146-1164, 1992.10

43）大岡龍三, 佐藤大樹, 村上周三：海風の内陸部進入に関するメソスケー ル数值解析と平均運動エネルギー収支分析に基づく海風阻害要因の定量 化，日本建築学会環境系論文集, Vol.73, No.632, pp.1201-1207, 2008.10

44) Weckwerth T. M., Wilson J. W., Wakimoto R. M.: Thermodynamic variability within the convective boundary layer due to horizontal convective rolls, Monthly Weather Review, Vol.124, No.5, pp.769-784, 1996.5 